\title{
Land Suitability of the Different Cultivars in the South Tyrol Wine Region (Italy)
}

\author{
Carlo Giovanni Ferretti \\ GIR Geo Identity Research, Bolzano, Italy \\ Email: carlo.ferretti@geoproject.it
}

How to cite this paper: Ferretti, C.G. (2020) Land Suitability of the Different Cultivars in the South Tyrol Wine Region (Italy). Agricultural Sciences, 11, 983-1006. https://doi.org/10.4236/as.2020.1111064

Received: October 14, 2020

Accepted: November 10, 2020

Published: November 13, 2020

Copyright $\odot 2020$ by author(s) and Scientific Research Publishing Inc. This work is licensed under the Creative Commons Attribution International License (CC BY 4.0).

http://creativecommons.org/licenses/by/4.0/

(c) (i) Open Access

\begin{abstract}
The geology and geomorphology of the territory as well as microclimate are local geographical features that serve as natural ecological resources. These factors influence the biosynthetic activities of plants and their phenology, promoting biodiversity and the qualitative predispositions of grapes and wine. South Tyrol is one of the smallest wine-growing regions in Italy, but owing to its position amid the Alps, it is also one of the most multifaceted, a region of wide geographical diversity and remarkable ecological range, hosting a concentration of many different vine varieties and high quality wines. This applied territorial research investigates the particular environmental circumstances that favour this case. A data set describing approximately 26,000 vineyards and 5450 hectares has been employed to evaluate 18 subzones of wines and vines selected from 86 new geographical units defined within the DOC wine region. A new environmental mapping scheme called VHTG is proposed, based on the ecological indicators of grape variety, altitude, topoclimate and the geopedology of the vineyards. Using the VHTG method analyses, the comparisons between the territories of origin and their vine varieties can be rendered simpler and more direct, and it can distinguish the most suitable ecological conditions of wine production zones. It is now possible to examine more in detail the land suitability of the different cultivars, defined by the use of the ecological indicators summarized in the VHTG method. White grape varieties such as Sylvaner and Veltliner prefer high altitudes between $600 \mathrm{~m}$ and $900 \mathrm{~m}$, a very high solar radiation SRI index from 80 to 95, and acidic sandy soils of silicate minerals. The most complete and intense tannic structure of regional Pinot Noir correlates to quite clayey soils with dolomite mineral, slightly alkaline, on vineyards at altitudes between 350 $\mathrm{m}$ and $410 \mathrm{~m}$, with rather low SRI index from 60 to 75. Similar geopedological conditions favour Gewürztraminer, which, however, requests SRI from 75 to 85. Merlot and Cabernet vines are best expressed in the hottest regional sub-zones, on moderately clayey subalkaline soils at $250-350 \mathrm{~m}$ of altitudes
\end{abstract}


and SRI around 80. The indigenous red grape variety Lagrein is mostly localized on alluvial cone at altitudes under $350 \mathrm{~m}$, on soft and ventilated acid sands with volcanic silicate minerals.

\section{Keywords}

Ecological Indicator, Wine Quality, Vineyards, Topoclimate, Geographical Identity, Terroir, Soil, Alto Adige-Südtirol, Geographical Unit, VGI

Vineyard Geological Identity, SRI Solar Radiation Identity, Geopedology, Alpine Ecosystem

\section{Introduction}

The zoning of a wine-growing region involves its subdivision into small areas within which the natural features of the environment define a homogeneous and characteristic ecosystem, distinguishable from the adjacent ones. Zoning is a complex process that takes its cue from the concept of "terroir" [1] [2] [3] [4] [5], and consists of an integrated and interdisciplinary study, aimed at dividing the territory according to its suitability for a specific crop [6]. To do this, it is necessary to read and precisely catalog all those environmental elements that can affect the vegetative, productive and qualitative expression of cultivation. In several territorial studies, the analysis of the geological and geographical component was sometimes attempted in a subsidiary way, with greater analytical attention to the agronomic soils aspects [7]-[12]. This may be partially plausible by the investigation of restricted zones, geologically simple and homogeneous [13]. On the other hand if we consider wine-growing regions, comparing many territories, as well as for the study of restricted areas with multifaceted geographical situations or for the meticulous comparison between vineyards, geopedology may be complex and variable; thus a detailed evaluation of the geological component of both terroir and soil is essential [14]-[20].

In very complex geographical environments, such as the mountainous one of the Alps, separating the evaluation of some geographical concepts from pedological, biologic, technical and cultural components could provide meaningful scientific value. Geological, geographic and anthropological conditions constitute here the distinctive elements of many wine-growing areas. They form a set of determining factors or ecological indicators that can qualify the uniqueness of a territory, its vineyards and its wines. Among these factors are geography and landforms, geopedology, altitude, climate, sun exposure and grape vine variety. To date these elements have never been linked together by studies concerning the South Tyrol wine-growing region. A single ecological element does not necessarily determine the specificity of place for a particular grape variety; rather it is the intersection of many geographical elements that creates distinctive conditions for vineyards and their wines [21]. It is therefore necessary to plan out a 
new environmental representation of the whole region, and set up on a homogeneous analytical basis, which makes it possible both to evaluate the different ecological elements of the subzones and to compare them with each other.

The first aim of the research is to propose a new system of wine territory analysis called VHTG (Variety-Height-Topoclimate-Geology), with the objective to codify a precise method suitable for this Alpine wine region. These are terroir's fixed geographical elements or ecological indicators, which, once cataloged, may be taken as a reference in future analytical evaluations of the wines quality from different sub-zones. A second topic of the research is to verify where the different cultivars are mainly cultivated within the sub-zones of South Tyrol wine region, and to combine them with the VHTG information.

Leaving aside the anthropic component of vineyard and cellar, this study must analyse a complex compilation of multidisciplinary data. We summarize these into three main families: the territory, the vine varieties and the quality of grape and musts. Specific skills and analytical methods are needed to extract value and new knowledge from complex territorial data sets. The goal is to identify ecological indicators that facilitate predictive analysis and to search for patterns in historical and territorial information to identify risks and opportunities in viticulture.

This evaluation of ecological indicators in the extensive South Tyrol mountains is difficult and not previously methodically studied or compared within the whole viticultural region.

We have sought new approaches for this applied research and to support decision-making in the viticultural sector, and new concepts are introduced to qualify the geographical identity of vineyards in a more precise and comparable way: vineyard geopedological identity (VGI) [14] and solar radiation identity index (SRI) [22]. These derive from a scientific analysis of the territory and allow discrimination and synthesis into simple indices of two complex environmental conditions: geopedology and topoclimate. These quantitative data help to characterize the potential of each local vineyard and are useful for discerning possible influences of ecological factors on the quality of musts and wines.

SRI and VGI method are useful to discriminate and predict territorial elements strongly connected to ecological diversity and wine quality. SRI is obtained from a high detailed geospatial analysis of the whole viticultural territory, and catalogs the topoclimatic value of each single vineyard within a simple numerical index rate between 0 - 100. A topoclimatic condition consists of numerous independent variables of the vineyard, such as slope, orientation, position and exposure, shading settings, the position and zenithal height of the sun in the horizon, and which, as a whole, are thus an important natural ecological resource of the territory. The topoclimatic potential of each vineyard compared to its altitude represents an interesting new key to distinguish the geographical differences between vineyards or wine-growing areas. The SRI index rate can then be related to the biosynthetic activity of the vines as well as to the quality of the 
vineyard's grapes and wine. The VGI procedure is based on detailed geopedological studies of vineyards soil sediments origin, mineralogy, chemistry and analyses on agrochemical or plant available chemistry. VGI information at regional scale should at least focuses on the following aspects of soil sediments: origin, stratigraphy, texture, silicate or carbonate character, clay minerals and groundwater if any is present.

The main relationships between soil mineralogy and wine quality are indirect, because parent material and bedrock influence soil macro- and micro-nutrients, soil chemical and physical parameters, vine rooting capacity, etc. However, to definitively substantiate the concrete influence of geology in viticulture, we can consider the evidence, for example, that the clay content and its $\mathrm{pH}$ range derive directly from soil minerals. Both of these geopedological features play vital roles in availability of nutrients essential for plant growth, and therefore for its biosynthetic activity and the grape fruits and musts quality [23] [24].

VGI and SRI allow definition of geological and geographical elements at varying scales from regional to that of an individual vineyard. Many studies conducted on wines from different South Tyrol location have shown that there are geographical factors related to the characteristics of wine, such as polyphenol and tannin profiles [14] [25] [26] [27] [28] [29].

This research is motivated by the need for new scientific analysis tools that allow us to compare the ecological status of every single vineyard in the varied and complex Alto Adige DOC wine region. The vineyards here are cultivated at altitudes between $200 \mathrm{~m}$ and $1300 \mathrm{~m}$, the highest in Europe. The average annual rainfall varies from $400-1200 \mathrm{~mm} /$ year. The region receives 300 sunny days per year [30] but the angle of sun exposure of the region's approximately 26,000 individual vineyards varies by $360^{\circ}$, many remaining in the shade for entire seasons and for long hours during summer days. Strong contrasts are also found in the slopes, from quite flat to extremely steep. The soils are composed of various grain sizes and mineralogies translating into very different soil characteristics from acidic to neutral or alkaline, often varying within short distances.

South Tyrol offers a unique geographical situation offering excellent opportunities for analysis and comparison of ecological indicators and of abiotic stresses that stimulate different phenological responses in the plants. South Tyrol grows over 40 varieties of grape vines, approximately half of which are employed in quantity production (Table 1 and Figure 1).

\section{Materials and Methods of Use}

\subsection{Geology and Origin of Soil Sediments}

Viticulture in South Tyrol is a complex mosaic with various main actors: over 5000 winegrowers and 216 wineries [31], 40 grape varieties and a multifaceted territory. We can evaluate the latter through targeted geological and geomorphological analysis. Within a few kilometres we find glaciers, deep valleys, sunny slopes and hills covered by vineyards. The variety of alpine landscapes found in 
Table 1. South Tyrol sub-regions. The number and type of varieties grown in the sub regions are indicative of the varietal predispositions of different geographical contexts. Thirty-five varieties grow in the Bassa Atesina while in Vinschgau there are only 29 varieties. A very low presence of vineyards can be interpreted as an agronomic experiment of low statistical value, thus varieties with less than 10 cultivated vineyards within the sub region are excluded. Consequently, the number of varieties decreases to 24 and 14 in those respective regions.

\begin{tabular}{|c|c|c|c|c|c|c|c|}
\hline \multirow{2}{*}{ Sub-Region } & \multicolumn{3}{|c|}{ Vineyards } & \multicolumn{2}{|c|}{ Variety $\%$} & \multirow{2}{*}{$\begin{array}{c}\text { No. of } \\
\text { varieties } \\
(>10 \\
\text { vineyards })\end{array}$} & \multirow{2}{*}{$\begin{array}{l}\text { Most } \\
\text { cultivated } \\
\text { grape } \\
\text { varieties }\end{array}$} \\
\hline & $\begin{array}{l}\text { Area (Ha) } \\
\text { (\% on total) }\end{array}$ & No. & $\begin{array}{l}\text { Altitude } \\
\text { (m asl) }\end{array}$ & White & Red & & \\
\hline Eisacktal & $\begin{array}{l}418.4 \\
(8 \%)\end{array}$ & 2848 & $\begin{array}{l}385 \\
976\end{array}$ & 89 & 11 & $\begin{array}{c}30 \\
(21)\end{array}$ & $\begin{array}{l}\text { Kerner, Silvaner, } \\
\text { Müller Thurgau, } \\
\text { Gewürztraminer, } \\
\text { Riesling, Veltliner }\end{array}$ \\
\hline Meraner & $\begin{array}{c}365.1 \\
(7 \%)\end{array}$ & 2227 & $\begin{array}{c}267 \\
1114\end{array}$ & 49 & 51 & $\begin{array}{c}31 \\
(22)\end{array}$ & $\begin{array}{l}\text { Vernatsch, } \\
\text { Weissburgunder, } \\
\text { Sauvignon, } \\
\text { Blauburgunder, } \\
\text { Chardonnay }\end{array}$ \\
\hline Vinschgau & $\begin{array}{l}79.5 \\
(2 \%)\end{array}$ & 946 & $\begin{array}{c}514 \\
1311\end{array}$ & 50 & 50 & $\begin{array}{c}29 \\
(14)\end{array}$ & $\begin{array}{c}\text { Blauburgunder, } \\
\text { Riesling, Vernatsch, } \\
\text { Weissburgunder, } \\
\text { Zweigelt }\end{array}$ \\
\hline Adige Valley & $\begin{array}{c}290.4 \\
(5 \%)\end{array}$ & 1460 & $\begin{array}{c}245 \\
1012\end{array}$ & 72 & 28 & $\begin{array}{c}26 \\
(13)\end{array}$ & $\begin{array}{c}\text { Sauvignon, } \\
\text { Weissburgunder, } \\
\text { Chardonnay, } \\
\text { Lagrein, Merlot }\end{array}$ \\
\hline Bolzano & $\begin{array}{l}691.4 \\
(13 \%)\end{array}$ & 3522 & $\begin{array}{c}234 \\
1323\end{array}$ & 40 & 60 & $\begin{array}{c}33 \\
(19)\end{array}$ & $\begin{array}{l}\text { Vernatsch, Lagrein, } \\
\text { Gewürztraminer, } \\
\text { Weissburgunder, } \\
\text { Müller Thurgau }\end{array}$ \\
\hline Oltradige & $1672.8(31 \%)$ & 7411 & $\begin{array}{l}213 \\
811\end{array}$ & 63 & 37 & $\begin{array}{c}32 \\
(23)\end{array}$ & $\begin{array}{l}\text { Weissburgunder, } \\
\text { Vernatsch, } \\
\text { Gewürztraminer, } \\
\text { Chardonnay, } \\
\text { Blauburgunder, } \\
\text { Sauvignon }\end{array}$ \\
\hline Bassa Atesina & $1842.1(34 \%)$ & 7365 & $\begin{array}{c}206 \\
1167\end{array}$ & 67 & 33 & $\begin{array}{c}35 \\
(24)\end{array}$ & $\begin{array}{c}\text { Pinot Gris, } \\
\text { Chardonnay, } \\
\text { Gewürztraminer, } \\
\text { Blauburgunder, } \\
\text { Lagrein }\end{array}$ \\
\hline
\end{tabular}

South Tyrol and its geological character create extremely fertile conditions for biodiversity [32] [33].

These environmental limitations are accompanied by a further selective environmental element: the multiple and complex geopedological varieties, mineral and physical composition of vineyard soils. In South Tyrol there are more than 150 parent rocks, each with its own mineral components, from which soils have 


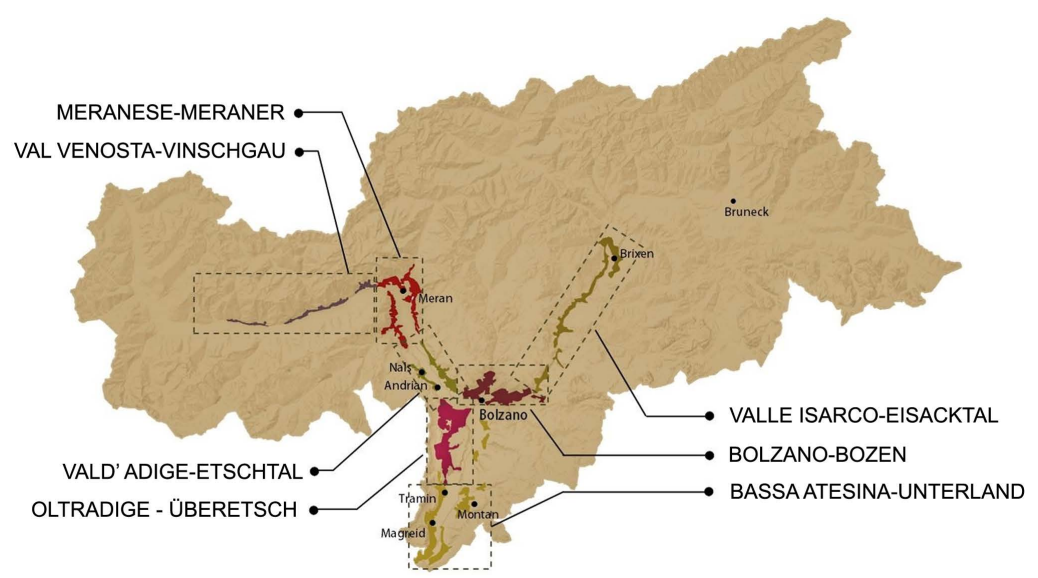

Figure 1. South tyrol, with locations of vineyards, geographic and geopedological sub-regions.

been formed, and many geomorphological processes that have elaborated and laid down the soil sediments over the millennia [34] [35] [36] [37]. The soil sediments are composed of a highly varied mixture of minerals. The composition of the soils can radically change between neighbouring vineyards because they derive from varied parent rocks: volcanic porphyry in the Bolzano valley basin, metamorphic rocks with quartz, shale and mica in the Etschtal and Eisacktal valleys, and ancient sedimentary rocks with sandstone marl, limestone and dolomite minerals in the southern part of South Tyrol.

Alpine geological history has defined all of the geographical elements that characterize the territory and with it many natural ecological elements that control the phenological behaviour of the vines. During the formation of the region's mountains and deep valleys the most friable rocks advanced the formation of morphological terraces, today cultivated with vineyards. Glaciers, rivers and landslides shaped these morphological terraces and thin sediment coulters were set both at the margin of the valley floor and along the steep valley sides. The properties of the soils are influenced by the geological history of the territory, shaping their physical structure, mineral composition and acidity. To introduce this comparison of geographical areas and vineyard/soil combinations this study first considers the parent rocks that are the source of soil minerals.

A rational geological model facilitating a regional wine analysis has been developed. It distinguishes four main districts and families of parent rocks: metamorphic, volcanic and plutonic, ancient sedimentary and dolomitic (Figure 2).

The first two, metamorphic and volcanic, are located respectively in the north and centre of South Tyrol, possessing predominantly silicate and quartz minerals and yielding sandy, stable and acidic soils. Ancient Permian sedimentary rocks emerge only along a thin belt and support vineyards in the south central portion of South Tyrol, but are very important for some varieties of vine because the soils have a finer texture, a low percentage of clays, are coloured by iron oxides and contain calcium carbonate, resulting in a moderately alkaline soil. In areas of dolomitic rock at the southernmost headland of the region, the presence of 


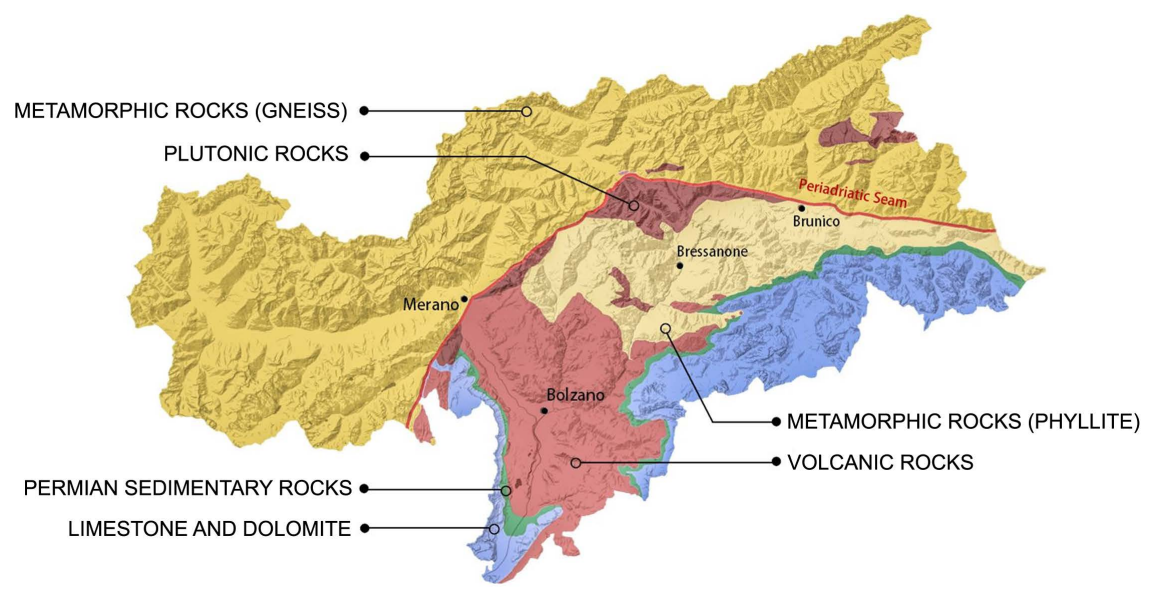

Figure 2. Semplified geological model of South Tyrol, divided into significant regional areas for this study (Modified from [38]).

dolomite mineral naturally reduces the soil's acidity. Unlike limestone, of which dolomite is a close relative, this mineral is less soluble and the structure of its resulting soils remains much more stable and porous over time, facilitating cultivation even on the valley floor with quite shallow groundwater.

\subsection{Geopedology of the South Tyrol Sub-Regions}

We proceed to a regional geological analysis by dividing South Tyrolean vineyard areas into seven geographical sub-regions (Figure 1 and Table 1) to describe the area's geopedology in better detail. Please note that South Tyrol is a bilingual Italian and German region so every toponym generally has two names. While we attempt to respect this assumption, in some cases for the requirements of graphic or scientific synthesis one of the two names may be missing.

- Eisacktal: Foliated fine grained metamorphic parent rocks, quartz phyllite, localized areas of granite, dolomite or ancient sediments. Weathered mica schist and sandy gravel soils, sediments of glacial origin and mostly terraced on slopes. Young and thin soils with an acid reaction. Soils of fluvial-glacial origin near Brixen, set on smooth hills and highlands where the granite and quartz component is greater.

- Meraner and Vinschgau: Foliated coarse grained metamorphic parent rocks, quartz gneiss. Young and thin soils, water permeable with acid reactions. Porous weathered soils with high gravel content on slopes and hills, sandy in valleys.

- Adige Valley: Local volcanic rocks combined with metamorphic sediments from Vinschgau, or dolomite components on the alluvial fans of the right side of the valley. Red porphyry base, high quartz and silicate mineral content, an acidic reaction in the soft sandy gravel soils in Terlan. Coarse material with water-permeable limestone in Nalles and Andrian, neutral to sub alkaline soil reaction. Sediments of glacial origin, mostly terraced on slopes, weathered sandy gravel soils. 
- Bolzano: Parent rocks are volcanic ignimbrite with subordinate metamorphic sediments from the lateral valleys. Porphyry base, high content of quartz and silicate minerals, moderate acid reaction in the soft sandy gravel soils set on Talvera torrent alluvial fans. The hills on the east side of the Bolzano morphological bowls originated as alluvial sediments from the Eisacktal, compact sandy gravel soils. Glacial origin and mostly terraced sediments on slopes, mostly quartz and silicate minerals from porphyry and fine grained portions from metamorphic rocks. Weathered sandy gravel soils, acidic.

- Oltradige: Limestone, porphyry and local ancient sediment rock formations with metamorphic sediments from north of the region. A mixed collection of parent rocks make up compact sandy neutral to moderately alkaline soils. Glacial sediments near Cornaiano/Girlan have resulted in acidic and very compact sandy soils. Local enrichment of soils composed of fine grained coloured loam, almost at the base of ancient sedimentary rock outcrops on steep valley sides. Terraced sediments of glacial origin on slopes composed of sandy soils with many mixed minerals.

- Bassa Atesina: Local limestone, dolomite, and ancient sedimentary rocks mixed with porphyry and metamorphic deposits from north of the region. Mostly mixed loamy rubble with sandy marl on the lower portions of both valley sides. Near the villages of Tramin and Montan are fine soils of fluvial-glacial origin from ancient sedimentary rocks, with a significant silty-clayey component coloured by iron oxides. Calcium carbonate and dolomite minerals result in weakly alkaline to alkaline soils. In the southernmost valley floors groundwater occurs below the vine root level. Soils are loamy and clayey with dolomite minerals that range in $\mathrm{pH}$ range to sub-alkaline. Minerals of almost $100 \%$ dolomite origin make up the Magreid alluvial fan.

\subsection{Territorial Morphology of the Wine Region}

In South Tyrolean viticulture, vineyards' geographical conditions have always been of great importance. This is a practical requirement, since the farmlands of the Alpine valleys have a narrow range, limited between the impervious areas, the high mountain altitudes and the valley floors, originally unhealthy, swampy and often flooded. Over the centuries, farmers have sought optimal locations to save rural space and to ensure good yields and wines. Exposure, altitude and geographical position play a fundamental role here, regulated by the morphological and microclimatic complexity of the Alpine and Dolomite valleys. The vineyards occupy approximately 5450 hectares, only $0.6 \%$ of the land area of South Tyrol, with $93 \%$ occupied by high mountains, forests, woods and meadows at high altitude [39].

Alpine morphology results in strong vegetational and climatic contrasts. This is a consequence of a multiform territory, almost exclusively mountainous and with very accentuated differences in elevation between the valley floor and the peaks. The geography and landforms of this territory greatly reduce the availa- 
bility of rural land and influence wine-growing practices. It is an energetic geological environment, constantly evolving over recent millennia, always seeking a new geomorphological balance. From this derives the complex heterogeneity of the soils, the deep valleys, the steep slopes and the high mountains, causing not only contrasting conditions of altitude, exposure and gradient, but also variations in microclimate, wind, air temperatures and day-night temperature excursions which differ greatly even at the vineyard scale. For example, consider how vines must necessarily be supported by greater solar radiation with increase in altitudes to compensate for a more unfavourable energy balance [40] [41]. Consequently, ecological and territorial selection indicators are very important. In this study the topoclimate information is synthetized as the SRI topoclimate index, representing the amount of solar radiative energy available to each vineyard.

\subsection{Ecological Indicators and Geographical Units}

Data from studies resulting in the recent subdivision of this wine-growing area into restricted units were applied to this evaluation of ecological indicators [42]. These 86 additional geographical units were delimited on a qualitative, historical and traditional basis. Each unit is combined with those specific vine varieties that are best adapted to its geographical conditions.

To outline the most significant ecological indicators on a wide regional scale, we consider four VHTG main variables: vine variety, height, topoclimate, and geopedology (Table 2). A precise classification and comparison of these four elements provides substantial indications for evaluating qualitative and productive differences, both in terms of grape varieties and quality of wines, even on a regional scale. For each geographical unit, an analysis was carried out by overlapping territorial and historiographic information that qualifies the specific geographical identity of each individual place. This evaluation references a closed and well-defined Alpine geographical system containing many ecological variables and resulting in comparisions between territories and wines.

Geopedology has been classified using the VGI method [14]. The VGI is compiled using data and information obtained using the research technologies of applied geology, documenting in a comparable manner all of the physical, mineral and chemical characteristics of the soil sediments.

Topological parametrization of every vineyard was obtained using the SRI Solar Identity index analysis [22]. SRI is an index calculated through geospatial analysis of the entire viticultural territory and is capable of detailed classification of the different topoclimate characteristics of vineyards. Any single vineyard can be identified via its own SRI index value. It effectively describes direct exposure to solar radiation and consequent ground level diurnal temperatures.

\subsection{Mineralogy of the Soil Sediments}

A better understanding of the mineralogical and chemical composition of the 
Table 2. Quantitative matrix of the main ecological indicators of the geographical units, resulting in the VHTG matrix.

\begin{tabular}{|c|c|c|c|c|c|c|c|c|c|}
\hline & (V) Variety & & & & $(\mathrm{H})$ & $(\mathrm{T})$ & (G) & Geopedology & \\
\hline $\begin{array}{c}\text { Municipality/ } \\
\text { Geographic Units }\end{array}$ & $\begin{array}{l}\text { Wine/vine } \\
\text { variety }\end{array}$ & $\begin{array}{l}\text { Vineyard } \\
\text { No. }\end{array}$ & $\begin{array}{l}\text { Area } \\
(\mathrm{Ha})\end{array}$ & $\%$ & $\begin{array}{l}\text { Altitude } \\
\text { (m asl) }\end{array}$ & $\mathrm{SRI}_{\text {Med }}$ & $\begin{array}{l}\text { Parent rocks } \\
\text { (prevalent) }\end{array}$ & $\begin{array}{c}\text { Soil } \\
\text { texture } \\
\text { and } \mathrm{pH} \\
\text { reaction }\end{array}$ & $\begin{array}{l}\text { Minerals } \\
\text { (most } \\
\text { represented } \\
\text { and } \\
\text { markers) }\end{array}$ \\
\hline South Tyrol & All Wine Region & 26.135 & 5.365 & $100 \%$ & $433 \pm 167$ & $75.6 \pm 7$ & $\begin{array}{c}\text { More than } 150 \\
\text { parent rock } \\
\text { formations: } \\
\text { metamorphic, } \\
\text { volcanic, plutonic, } \\
\text { ancient sediments, } \\
\text { limestone and } \\
\text { dolomite }\end{array}$ & & \\
\hline $\begin{array}{c}\text { Salorno Cortina/ } \\
\text { Pfatten, Giatl, Punggl }\end{array}$ & All vineyards & 894 & 237 & $4 \%$ & $209 \pm 1$ & $70.1 \pm 4$ & & & $\begin{array}{l}\text { Quartz, } \\
\text { chamosite, }\end{array}$ \\
\hline $\begin{array}{l}\text { Salurn-Pfatten. } \\
\text { Giatl. Punggl }\end{array}$ & Chardonnay & 231 & 64 & $27 \%$ & $209 \pm 1$ & $70.1 \pm 4$ & $\begin{array}{l}\text { All the rocks } \\
\text { from South } \\
\text { Tyrol region }\end{array}$ & $\begin{array}{l}\text { Neutral to } \\
\text { alkaline } \\
\text { fine sand }\end{array}$ & $\begin{array}{l}\text { muscovite, } \\
\text { khaolinite, } \\
\text { dolomite, }\end{array}$ \\
\hline $\begin{array}{l}\text { Salurn-Pfatten, } \\
\text { Giatl, Punggl }\end{array}$ & $\begin{array}{l}\text { Pinot Gris } \\
\text { (Ruländer) }\end{array}$ & 457 & 126 & $53 \%$ & $209 \pm 1$ & $70.2 \pm 4$ & & & $\begin{array}{l}\text { albite, } \\
\text { orthoclase }\end{array}$ \\
\hline $\begin{array}{l}\text { Cortaccia/Brenntal } \\
\text { Frauenriegel Rungg }\end{array}$ & All vineyards & 499 & 114 & $2 \%$ & $299 \pm 62$ & $73.1 \pm 6$ & Ancient & & $\begin{array}{l}\text { Quartz, } \\
\text { muscovite, }\end{array}$ \\
\hline $\begin{array}{c}\text { Brenntal Frauenriegel } \\
\text { Rungg }\end{array}$ & Cabernet & 54 & 12 & $11 \%$ & $293 \pm 33$ & $73.7 \pm 5.3$ & $\begin{array}{c}\text { sediments } \\
\text { (limestone } \\
\text { marls, clay and }\end{array}$ & $\begin{array}{l}\text { Neutral to } \\
\text { alkaline } \\
\text { loamy sand }\end{array}$ & $\begin{array}{l}\text { dolomite, } \\
\text { kaolinite, } \\
\text { calcite, }\end{array}$ \\
\hline $\begin{array}{c}\text { Brenntal Frauenriegel } \\
\text { Rungg }\end{array}$ & Merlot & 47 & 11 & $10 \%$ & $276 \pm 46$ & $72.3 \pm 4$ & sandstones) & & $\begin{array}{l}\text { ematite, } \\
\text { clinochlore }\end{array}$ \\
\hline Cortaccia/Penon Kofl & Sauvignon Blanc & 154 & 13 & $42 \%$ & $528 \pm 41$ & $73.1 \pm 7$ & $\begin{array}{c}\text { Dolomite } \\
\text { and glacial } \\
\text { sediment } \\
\text { (porphyry and } \\
\text { metamorphic) }\end{array}$ & $\begin{array}{c}\text { Alkaline } \\
\text { sand and } \\
\text { gravel }\end{array}$ & $\begin{array}{l}\text { Dolomite, } \\
\text { quartz, } \\
\text { muscovite, } \\
\text { orthoclase }\end{array}$ \\
\hline Cortaccia/Graun & All vineyards & 92 & 29 & $1 \%$ & $805 \pm 43$ & $85.5 \pm 4$ & $\begin{array}{c}\text { Glacial } \\
\text { sediments } \\
\text { (mostly }\end{array}$ & $\begin{array}{l}\text { Neutral to } \\
\text { alkaline }\end{array}$ & $\begin{array}{l}\text { Quartz, } \\
\text { muscovite, } \\
\text { orthoclase, }\end{array}$ \\
\hline Graun & Müller Thurgau & 72 & 22 & $76 \%$ & $808 \pm 45$ & $85.2 \pm 4$ & $\begin{array}{l}\text { Metamorphic } \\
\text { and dolomite) }\end{array}$ & sand & $\begin{array}{l}\text { kaolinite, } \\
\text { dolomite }\end{array}$ \\
\hline $\begin{array}{l}\text { Tramin/Plon, } \\
\text { Söll, St. Peter }\end{array}$ & Gewürztraminer & 563 & 131 & $38 \%$ & $412 \pm 100$ & $74.5 \pm 6$ & $\begin{array}{c}\text { Ancient } \\
\text { sediments } \\
\text { (limestone marls, } \\
\text { clay and } \\
\text { sandstones) }\end{array}$ & $\begin{array}{l}\text { Neutral to } \\
\text { alkaline } \\
\text { loamy sand }\end{array}$ & $\begin{array}{c}\text { Quartz, } \\
\text { muscovite, } \\
\text { dolomite, } \\
\text { kaolinite, } \\
\text { calcite, } \\
\text { ematite, } \\
\text { clinochlore }\end{array}$ \\
\hline EGNA/Mazon & $\begin{array}{c}\text { Pinot Noir } \\
\text { (Blauburgunder) }\end{array}$ & 172 & 66 & $80 \%$ & $388 \pm 34$ & $67.2 \pm 5$ & $\begin{array}{c}\text { Ancient } \\
\text { sediments } \\
\text { (limestone marls, } \\
\text { clay and } \\
\text { sandstones) }\end{array}$ & $\begin{array}{l}\text { Neutral to } \\
\text { alkaline } \\
\text { loamy sand }\end{array}$ & $\begin{array}{c}\text { Quartz, } \\
\text { muscovite, } \\
\text { dolomite, } \\
\text { kaolinite, } \\
\text { calcite, } \\
\text { ematite, } \\
\text { clinochlore }\end{array}$ \\
\hline
\end{tabular}




\begin{tabular}{|c|c|c|c|c|c|c|c|c|c|}
\hline $\begin{array}{l}\text { Caldaro/St. } \\
\text { Josef Barleit } \\
\text { Plantaditsch } \\
\text { St. Josef Barleit } \\
\text { Plantaditsch }\end{array}$ & $\begin{array}{l}\text { Kalterersee } \\
\text { Vernatsch }\end{array}$ & 247 & 211 & $35 \%$ & $289 \pm 31$ & $74.1 \pm 4$ & $\begin{array}{c}\text { Glacial } \\
\text { sediments } \\
\text { (ancient } \\
\text { sediments, } \\
\text { porphyry and } \\
\text { metamorphic) }\end{array}$ & $\begin{array}{l}\text { Neutral to } \\
\text { alkaline } \\
\text { sand }\end{array}$ & $\begin{array}{l}\text { Quartz, } \\
\text { dolomite, } \\
\text { muscovite, } \\
\text { orthoclase, } \\
\text { calcite, } \\
\text { chamosite }\end{array}$ \\
\hline $\begin{array}{l}\text { APPIANO/Eppan, } \\
\text { Berg, Schulthaus }\end{array}$ & $\begin{array}{c}\text { Pinot Blanc } \\
\text { (Weißburgunder) }\end{array}$ & 134 & 32 & $63 \%$ & $552 \pm 19$ & $\begin{array}{c}77 \pm 3 \\
77.1 \pm 3\end{array}$ & $\begin{array}{l}\text { Dolomite and } \\
\text { glacial sediments } \\
\text { (porphyry and } \\
\text { metamorphic) }\end{array}$ & $\begin{array}{l}\text { Neutral to } \\
\text { alkaline } \\
\text { compact } \\
\text { sand }\end{array}$ & $\begin{array}{l}\text { Quartz, } \\
\text { dolomite, } \\
\text { muscovite, } \\
\text { orthoclase, } \\
\text { calcite, } \\
\text { chamosite }\end{array}$ \\
\hline $\begin{array}{c}\text { BOLZANO/Gries } \\
\text { Moritzing }\end{array}$ & All vineyards & 296 & 85 & $97 \%$ & $252 \pm 8$ & $75.9 \pm 2$ & $\begin{array}{l}\text { Porphyry distal } \\
\text { alluvial fan }\end{array}$ & $\begin{array}{l}\text { Acidic } \\
\text { ventilated } \\
\text { sand } \\
\text { gravel }\end{array}$ & $\begin{array}{l}\text { Quartz } \\
\text { muscovite, } \\
\text { albite, } \\
\text { orthoclase, } \\
\text { chamosite, } \\
\text { kaolinite, } \\
\text { dolomite }\end{array}$ \\
\hline Prazöll Vernatsch & $\begin{array}{l}\text { All vineyards } \\
\text { ST. } \\
\text { Magdalener } \\
\text { Vernatsch }\end{array}$ & 207 & 45 & $76 \%$ & $431 \pm 112$ & $\begin{array}{l}50.5 \pm 7 \\
80.9 \pm 6\end{array}$ & $\begin{array}{l}\text { Ancient fluvial } \\
\text { sediments } \\
\text { (porphyry and } \\
\text { metamorphic } \\
\text { phyllite) }\end{array}$ & $\begin{array}{l}\text { Acidic } \\
\text { compact } \\
\text { sands }\end{array}$ & $\begin{array}{l}\text { Quartz, } \\
\text { muscovite, } \\
\text { albite, } \\
\text { orthoclase, } \\
\text { dolomite }\end{array}$ \\
\hline $\begin{array}{l}\text { TERLANO/Siebeneich, } \\
\text { Kreut, Klaus, Vorberg }\end{array}$ & $\begin{array}{l}\text { All vineyards } \\
\text { Terlaner } \\
\text { Chardonnay, } \\
\text { Sauvignon B, } \\
\text { Pinot B. }\end{array}$ & 811 & 107 & $60 \%$ & $378 \pm 12$ & $77.2 \pm 8$ & $\begin{array}{c}\text { Porphyry } \\
\text { alluvial } \\
\text { fan, glacial on } \\
\text { deposits slopes } \\
\text { (with } \\
\text { metamorphic } \\
\text { gneiss) }\end{array}$ & $\begin{array}{l}\text { Acidic } \\
\text { ventilated } \\
\text { sand } \\
\text { gravel }\end{array}$ & $\begin{array}{c}\text { Quartz, } \\
\text { muscovite, } \\
\text { albite, } \\
\text { orthocl., } \\
\text { hydrothermal } \\
\text { alteration } \\
\text { minerals }\end{array}$ \\
\hline Merano/Küchelberg & $\begin{array}{l}\text { Meraner } \\
\text { Vernatsch }\end{array}$ & 149 & 25 & $0.5 \%$ & $267 \pm 29$ & $76.3 \pm 6$ & $\begin{array}{l}\text { Metamorphic } \\
\text { gneiss }\end{array}$ & $\begin{array}{l}\text { Acidic } \\
\text { compact } \\
\text { sand } \\
\text { gravel }\end{array}$ & $\begin{array}{l}\text { Quartz } \\
\text { muscovite, } \\
\text { albite, } \\
\text { orthoclase, } \\
\text { kaolinite, } \\
\text { chamosite, } \\
\text { paragonite }\end{array}$ \\
\hline $\begin{array}{l}\text { Castelbello-Ciardes/ } \\
\text { Kastelbell Juvaler }\end{array}$ & All vineyards & 36 & 1 & $0.1 \%$ & $773 \pm 78$ & $78.2 \pm 10$ & $\begin{array}{l}\text { Metamorphic } \\
\text { gneiss }\end{array}$ & $\begin{array}{l}\text { Acidic } \\
\text { sand } \\
\text { gravel }\end{array}$ & $\begin{array}{l}\text { Quartz } \\
\text { muscovite, } \\
\text { albite, } \\
\text { orthoclase, } \\
\text { kaolinite, } \\
\text { chamosite, } \\
\text { paragonite }\end{array}$ \\
\hline Funes/Nafen & All vineyards & 72 & 13 & $0.25 \%$ & $795 \pm 57$ & $86.8 \pm 3$ & $\begin{array}{l}\text { Metamorphic } \\
\text { phyllite and }\end{array}$ & $\begin{array}{l}\text { Acidic } \\
\text { fine }\end{array}$ & $\begin{array}{l}\text { Quartz, } \\
\text { muscovite, } \\
\text { orthoclase, }\end{array}$ \\
\hline Nafen & Kerner & 25 & 5 & $42 \%$ & $791 \pm 57$ & $86.6 \pm 3$ & intrusive rocks & sands & $\begin{array}{l}\text { kaolinite } \\
\text { dolomite }\end{array}$ \\
\hline Velturno/Schrambach & All vineyards & 62 & 2 & $0.15 \%$ & $656 \pm 57$ & $\begin{array}{l}80.4 \pm 6 \\
82.3 \pm 4\end{array}$ & $\begin{array}{c}\text { Metamorphic } \\
\text { phyllite }\end{array}$ & $\begin{array}{l}\text { Acidic } \\
\text { fine } \\
\text { sands }\end{array}$ & $\begin{array}{l}\text { Quartz, } \\
\text { muscovite, } \\
\text { orthoclase, } \\
\text { kaolinite }\end{array}$ \\
\hline
\end{tabular}




\section{Continued}

\begin{tabular}{cccccccccc}
\hline Villandro/Sauders & All vineyards & 252 & 32 & $1 \%$ & $647 \pm 59$ & $80 \pm 6$ & Metamorphic & $\begin{array}{c}\text { Acidic } \\
\text { fine } \\
\text { shyllite }\end{array}$ & $\begin{array}{c}\text { Quartz, } \\
\text { muscovite, } \\
\text { orthoclase, } \\
\text { kands }\end{array}$ \\
& Veltliner & 26 & 4 & $11 \%$ & $631 \pm 44$ & $77 \pm 6$ & &
\end{tabular}

soil sediments and the origin of some of the mineral macronutrients present were achieved through the use of X-ray diffraction analysis. The mineral soil composition and density influences grape quality and may indirectly the organoleptic properties of wine [43]. Silicate minerals express acidic soils, dolomite minerals give moderately alkaline $\mathrm{pH}$ values, while limestone favours alkaline soils. The content of clays and phyllosilicate minerals supports the cation-exchange capacity and the soil moisture [44]. Without going into the analytical detail of these facts, it is observed that these are some of the geopedological elements, which fundamentally influence the biosynthetic activity of plants and the quality of its fruits [23]. The knowledge of the mineralogical component of the soils has therefore an essential meaning in the terroir investigation of the South Tyrol wine region. To determine the crystalline phases of the soil sediments, 44 diffractometric analyses (XRD) have been done to complete the VGI method of classification for the vineyards. Qualitative powder diffraction analysis (XRD) allowed estimation of the crystalline phases representative of the different geographical areas.

\section{Results and Discussion}

\subsection{Analysis of the Geographical Areas and Ecological Indicators Descriptions}

We identified 18 wines and vines that are more present or characteristic of particular geographical areas, as indicated in the map in Figure 3.

In order to assign rigorous values to territorial data it was necessary to define which are most representative for this wine-growing research over a wide-ranging region. Drawing on experience with the South Tyrol model a new VHTG classification scheme composed of the factors of vine variety, height, topoclimate, and geopedology is proposed.

This scheme can facilitate future observation and assessment of the geographic factors of well-defined areas and classification of ecological indicators that are precursors of abiotic stress for the vines. These territorial data are transposed into a quantitative matrix that analyses vineyard altitudes, their topoclimates by means of the vineyard irradiation index (SRI), and the geopedological terroir using the VGI system. To complete the quantitative analysis, qualitative elements of the different areas are also considered, including basic information on air temperature, rainfall, prevailing winds and microclimate. In a multidisciplinary analysis involving various professional figures and scientists from different backgrounds, it is essential to provide a qualitative environmental description allowing more functional sharing of information. 


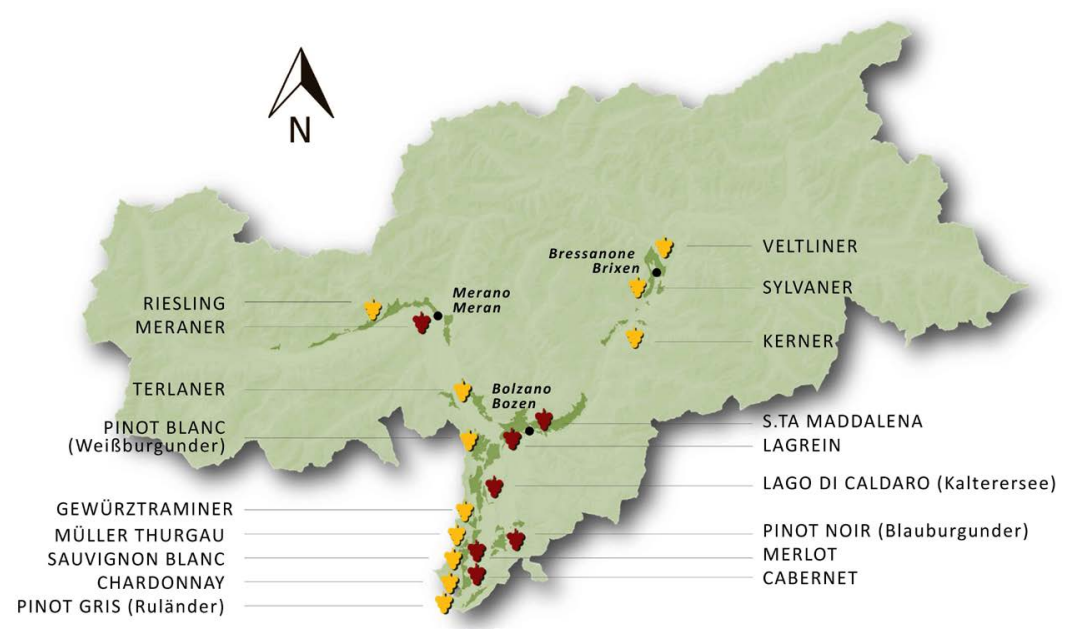

Figure 3. Geographical locations in the Alto Adige DOC region of 18 analysed vines and wines. Additional geographical units are shown in dark green.

\subsection{Incidence of SRI and Altitude on Grape Variety}

Figure 4 presents the graphs of SRI-altitude of each vineyard and the grape variety or wine of the geographical units. Comparison of the graphs clearly shows how these ecological indicators change from one area to another. The analysis of vineyards within the same area also provides indications of the range of variability characteristic of each vine variety. In addition to giving indications on the different ecologies of vine varieties, this relates each vineyard to the others and can facilitate evaluation of the influence of these ecological indicators on the characteristics of musts and wine.

The dispersion of the points in the SRI-altitude graphs reflects the ability of vine varieties to adapt to the abiotic stress caused by both altitude and topoclimate. From a graphic point of view the orientation and breadth of the data set distribution region can be clearly visualized, for example by using the kernel density estimation confidence prediction [45]. Figure 4 shows that at low altitudes the SRI data are more dispersed, the distribution region is quite vertical, and therefore solar radiation is less of a limiting factor for the vine. Where altitude becomes a limiting factor for the vine variety the distribution region is more inclined towards higher values, the SRI values increase. Some more resistant varieties have higher ranges of values at high altitudes, for example Riesling, Veltliner, Sylvaner, and Sauvignon Blanc. High altitude and low solar radiation are less limiting environmental conditions for these varieties than others that instead preferentially concentrate at lower altitudes, for example Chardonnay, Cabernet and Merlot. Thus this study confirms the importance of the measured topoclimate factor and that the SRI index distinguishes this ecological indicator in great detail. It may be interesting to evaluate how different SRIs for vineyards at the same altitude can indicate the quality of musts and wines, for example, measuring the tannins or the quantity of precursor molecules for their sensory impact. 

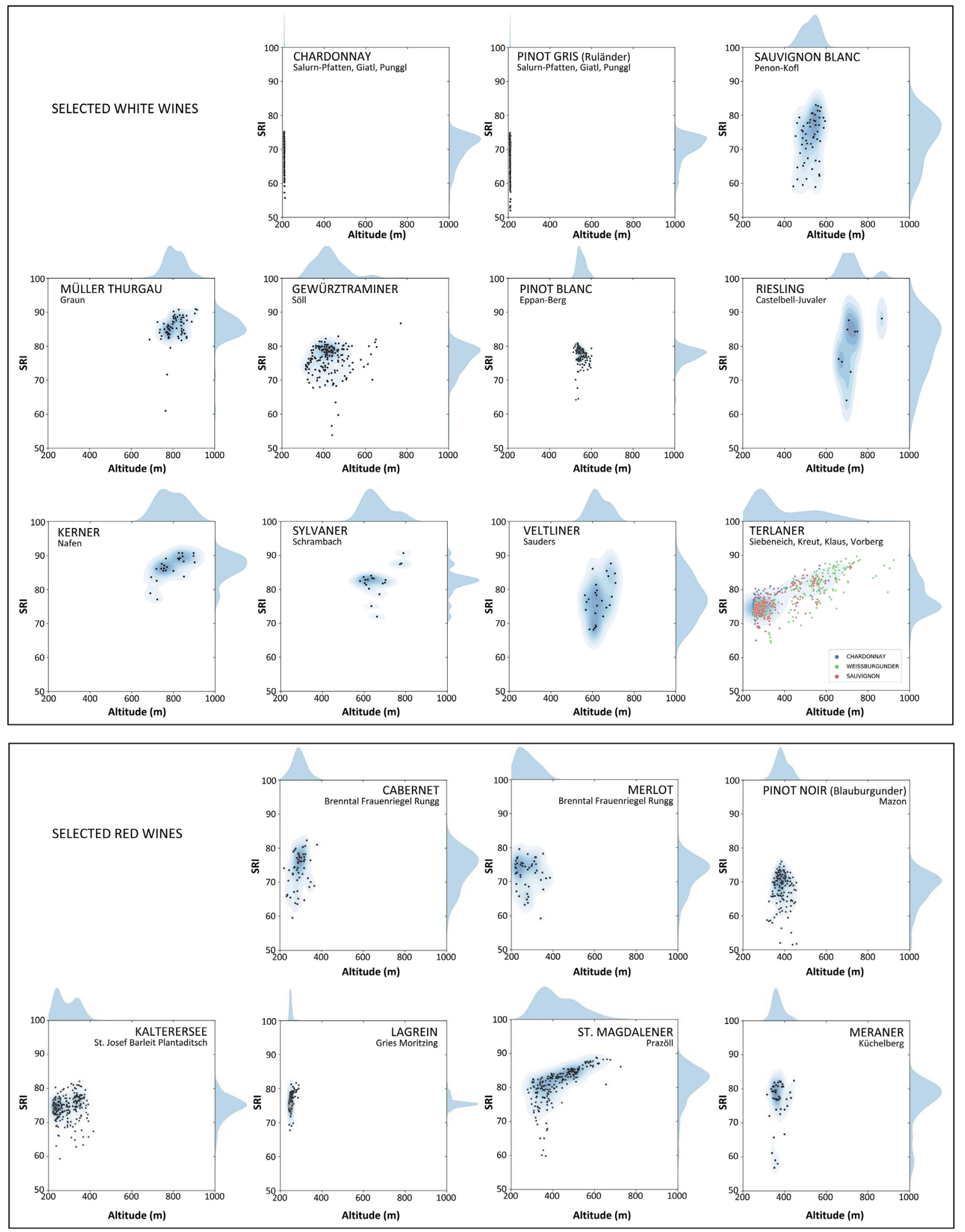

Figure 4. Ecological indicators of altitude and SRI for every vineyard in the selected units, shown above wine names. The points in the graph refer to single vineyards, Kernel density estimation and histograms in light blue help to better identify the regions with the highest concentration of points. 
A detailed analysis of the SRI factor at low altitudes shows a wide dispersion of SRI values, thus SRI does not seem to be a highly limiting element. But increasingly with altitude a highly selective effect is evident: solar radiation is more essential for plant growth and high values for SRI are therefore needed. See for example the graphs of St. Magdalener, Terlaner, Sylvaner, Kerner, Müller Thurgau where with increases in altitude the vineyards with low SRIs disappear and those that remain converge on higher SRI values.

Terlaner is a cuvee of several white grape varieties grown near the village of Terlano. The data representing three of these varieties are therefore presented. It is interesting that these grape varieties seem to be connected to different ranges of SRI and heights. Chardonnay is more widespread at lower altitudes less than $450 \mathrm{~m}$ : beyond this it requires high SRI. Sauvignon Blanc is widespread at low and intermediate elevations but below $600 \mathrm{~m}$. Pinot Blanc has a wider distribution of altitude and SRI and grows in vineyards up to those that exceed $900 \mathrm{~m}$ above sea level.

Using the schemes and the proposed classifications it is possible to distinguish and compare the topoclimate ecological indicators on a regional scale even in complex geographical environments. Future detailed analyses will require more refined comparison data; however qualitative descriptions of the areas on a regional scale already highlights geographical elements that will allow new comparisons information between grape varieties, vineyards and wine quality.

The graphs of Figure 4 simplify to read and compare the geographical distribution of the vineyards, in order to evaluate a different ecological compatibility of the vine variety to the territory. It can be observed, for example, how the vineyards of red wine varieties are scattered in the diagram: Pinot Noir is favorably associated with very low SRI values. The autochthonous Vernatsch grape of the S.ta Maddalena, Meraner and Kalterersee DOC wines adapts to very variable altitude conditions, but high solar radiation conditions are ideal. The quality characters of these three Denomination of Controlled Origin wines are quite different thanks to the different vineyards geographical position. The vineyards distribution of the St. Maddalena graph also indicates that, as the altitude increases, the SRI index becomes a highly selective factor. Cabernet and Merlot wines require low altitudes, to favor high temperatures, and the best quality wines are guaranteed by very high SRI values. Lagrein, an indigenous grape variety, is aided by medium-high SRI and medium-low altitudes, on sub-acid soils with a predominant skeleton of pebbles and coarse grains.

\subsection{Grape Variety and Ecological Indicators}

The VHTG data collected in this study indicate geographical ecosystems characteristic of each analysed areas. The purpose of this research is to provide a base of homogeneously defined territorial information within the entire wine region, which we can refer to evaluate any different behaviours in both grapevine vegetative growth and wine's quality from different areas. Future wines evaluations 
and comparisons by means of vineyards monitoring, wine analysis or wine tasting will benefit from the data of this territorial classification. It is not the object of this research to analyse the geographical or pedological data in excessive detail in competition with a targeted evaluation of vineyards or specific varieties, but to identify geographic correlations between wide ranging regional territories and their wines. We can report the following main geographical markers observed in the geographical units, listed below according to grape variety or wine:

- Cabernet and Merlot: Fine soils, low altitude, and warm climate [46] [47] are the distinctive geographical features for these varieties. SRIs vary greatly depending on the exposure and inclination of the vineyard. High SRI values are very important to support the long and complete ripening of the fruit in the final phase [48] [49]. From the SRI/H graph, individual vineyards with these exclusive characteristics can be distinguished. The qualitative assessments listed may be used as a basis for further study of wines from different geographical units.

- Pinot Noir (Blauburgunder): Low SRI indices. The area is affected by the shadow of the mountains during long periods of the year and in the morning hours during the summer. The wide dispersion of the index confirms the adaptability of the grape variety to different geographical conditions and selective microclimates. In South Tyrol it is also cultivated at high altitudes above $1000 \mathrm{~m}$, thus in low mountain microclimates, but in this case the SRI values must be high. This grape variety is recently spreading in Vinschgau, where it is now the most cultivated (Table 1). Regarding the quality of the wine, it appears that greater completeness in the tannins and aromatic expression are connected to the unit of Mazon, possessing texturally fine, alkaline soils and highly aerated vineyards [42].

- Chardonnay and Pinot Gris (Ruländer): Low altitude, high temperatures, medium-low SRI and alkaline soils of the valley floor support a stylistic line of these wines which are now popular. SRI values are very scattered. Low altitude, high temperatures, medium-fine grained soils and almost constant wind are the most distinctive ecological factors of this wine area.

- Sauvugnon Blanc: This grape variety has a certain adaptability to different altitudes and soils, from acid to alkaline, but its aromatic line depends on the degree of ripeness of the fruit [50] [51] and varies greatly from area to area. In this zone, the mid-hill morphology is irregular and locally steep, thus SRIs are very variable. Sandy soil sediments are enriched with dolomite minerals and are therefore alkaline.

- Gewürztraminer: This grape adapts quite well to altitude and SRI, preferring fine, neutral to alkaline soils, a not too ventilated environment and day-night temperature changes. In the studied area SRI is varied due to the hilly morphology which exposes the vineyards in various directions from south to north-east. Higher SRI indices are measured at high altitudes, while air temperatures rise in the lower areas and near the valley floor so a reduction of SRI value is possible. 
- Lagrein: Typical wine of the South Tyrol region, here connected to porphyritic soils, sandy, ventilated, rich in quartz. To reach its best quality expression, this grape is cultivated at low altitudes where SRI is variable over a rather wide range, compensated by the warm microclimate of the morphological valley basin of Bolzano.

- Meraner, Kalterrersee, St. Magdalener: These traditional wines are produced with Vernatsch grapes and are typically connected to the territory, reflecting in their quality the different geographical conditions of their growing areas. These are very different from a geopedological point of view: silicate porphyritic soils from volcanic rocks in Bolzano, mixed soils with dolomite component in Caldaro and purely metamorphic in Meran. The microclimatic conditions are also different between these areas but they appear to share a similar mild Mediterranean climate.

- Pinot Blanc: This is a grape variety that is very adaptable to geographical conditions. The stylistic lines of the wines from different altitudes, SRIs and geopedology are different. Given the considerable diffusion of this grape variety over the territory and the high variation in quality of the wines, a more detailed specific study is desirable.

- Riesling, Kerner, Veltliner, Sylvaner: These are white vines growing in selective mountain climates and on sandy acid soils, with high solar radiation and large day-night temperature fluctuations. A similar mountain climate situation is identified for Müller Thurgau, which also adapts well to soils with neutral $\mathrm{pH}$, here growing at high altitude with abundant sun, the mountain climate is balanced by SRI values among the highest in the wine-growing region. These are all typical ecological elements of the Graun geographic unit.

- Veltliner: Very dispersed SRIs. The variety resists day-night temperature fluctuations and adapts to extreme conditions. The more resistant the grape variety, the greater the SRI dispersion, especially in the selective environment of mountain climate and high altitude.

- Kerner: SRI rises with altitude up to maximum values just greater than 90 , near the geographical limits of the region. High values derive from the regular southern exposure of the vineyards.

\subsection{Dataset Representation on Maps}

A goal of this research was to devise a cartographic representation form of the geospatial information, even at different scales. We are convinced that correct and clear images allow us to visualize and better understand complex geospatial concepts. Examples are presented in Figure 5, showing a 3D representation of the SRI ecological indicator, and Figure 6, showing the new geographical units in the southern part of South Tyrol and more detailed maps of both vineyards and grape varieties. For these maps new cartographic bases have been developed to aid the three-dimensional interpretation of the hilly and mountainous territory around the vineyards. 

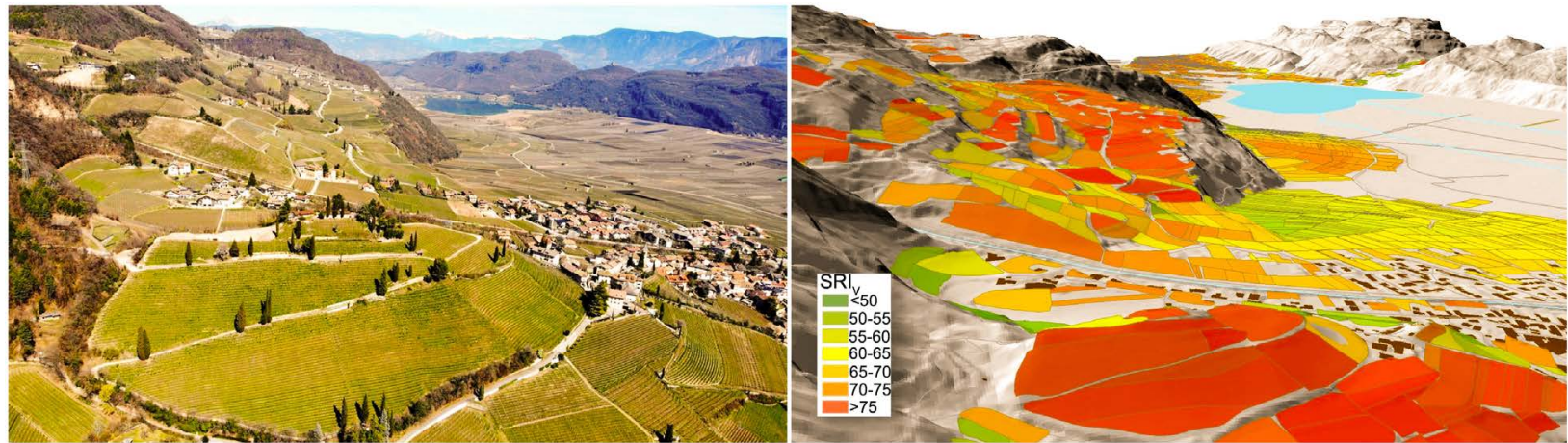

Figure 5. Comparative image from almost the same point of view between vineyard's of the Söll geographical unit and their SRI indexes.

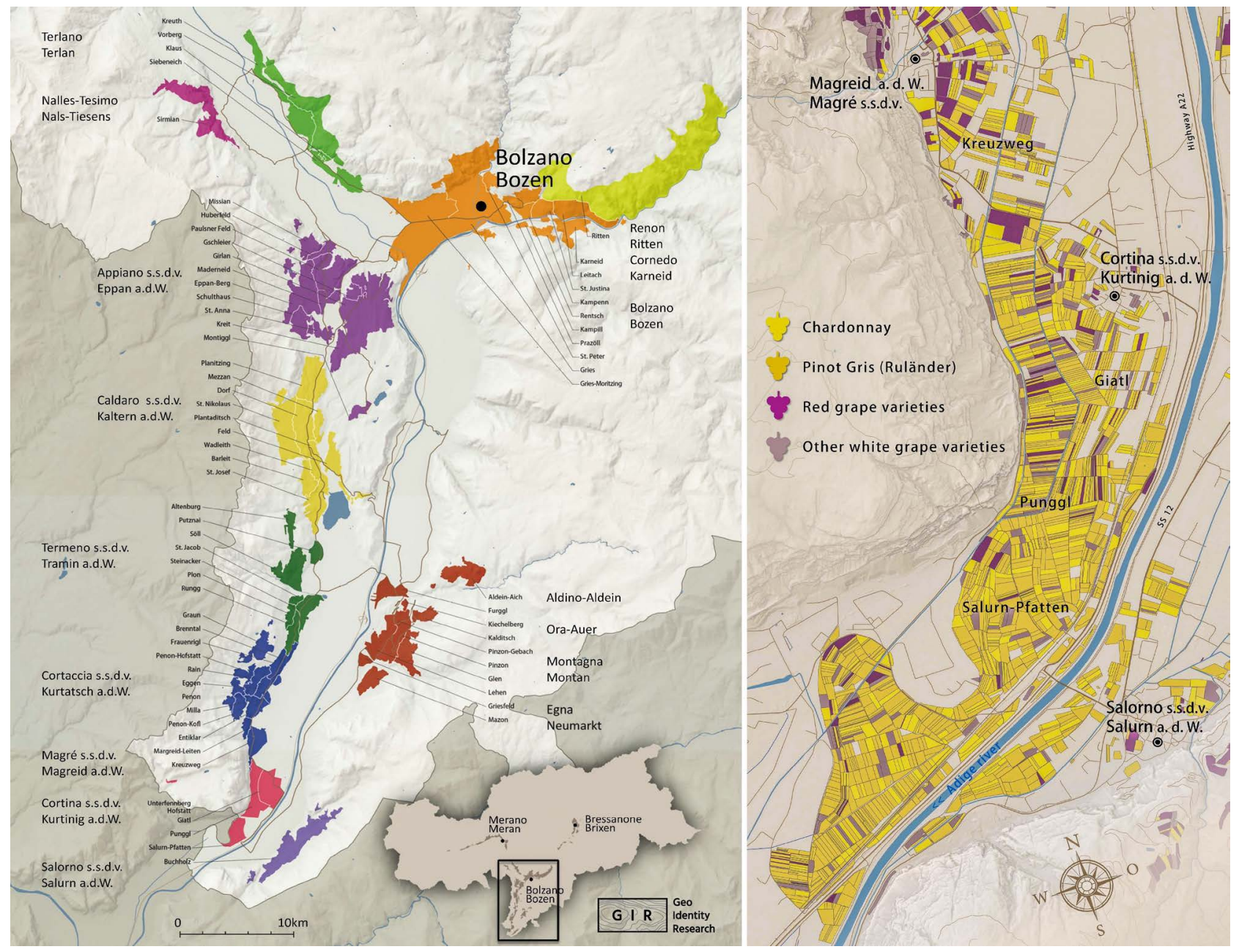

Figure 6. Detail of the proposed new geographical units in the southern part of South Tyrol, listed in their respective municipalities. Each unit is combined with a few grape varieties for the explicit purpose of quality wine production. On the right a map of the vineyards of the geographical units of Giatl, Punggl and Salurn-Pfatten, with detailed representation of their grape varieties.

In addition to information on ecological indicators in the alpine environment, this research has confirmed the necessity of an accurate geopedological classification for the territory to enable more precise soil maps [36] [52]. Given the ex- 
treme environmental complexity and the difficulty of accounting for all the geomorphological processes that have shaped the soils, local soil maps have so far encountered difficulties and are mainly based on spot data of agronomic soil measurements [12] [53] [54] [55] [56] [57]. Pedological maps should be combined with specific geopedological information. Simple geological maps are not enough to overcome the local criticality that is the result of unusual geographical complexity, and fail to yield a higher technical value to new agronomic maps. We are convinced that all the knowledge, datasets and geospatial information from both geopedological and agronomic scientific disciplines should be combined. Only in this way it is possible to obtain a more precise and faithful image of the territory as well as encouraging applied wine research in a complex alpine ecosystem.

\section{Conclusions}

The South Tyrol wine-growing region occupies a geographical complex Italian territory amid the Alps. This wine region is particularly suitable for studies of the geographical links between terroir, land suitability for viticulture and quality of their wines, because it represents a geographical system enclosed between high mountain ranges but with highly variable ecological features. A marked variability of landscapes and soils is present, with consequent difficulty in identifying territorial situations and ecological indicators contributing to biodiversity in the viticultural sector. To overcome these obstacles a new approach based on in-depth geological and morphological knowledge has been designed. The subdivision and separate analysis of ecological indicators summarized in the VHTG method provide a practical support for examining land suitability of the different cultivars in South Tyrol. This method collects multiple and complex environmental data in well-defined ecological categories and indices, so that it is easier to identify their link with the biosynthetic aspects of the vine and the quality of its wine. It is thus possible to identify with increased reliability both the natural ecological resources and the cultivars land suitability, in order to reduce environmental risks in viticulture and promote quality production.

The availability of large geographical databases and precise knowledge of the wine-growing territory has led to this research and to identification of the locations of prevalent vine varieties and quality wines in the South Tyrolean geographical area.

The ecological indicators of small geographical wine zones characteristic of 18 grape varieties and quality wines in the Italian Alto Adige DOC wine region were classified and analysed. The study applies new key elements for reading and interpreting a wide and multifaceted territorial data set with high volume and variety of environmental data. The research clarifies the primary ecological indicators summarized in the VHTG scheme: vine variety, height, topoclimate, and geopedology. New relational databases with structured data of every wine 
zone have been created. These will favour future interdisciplinary analyses, as well as comparisons between geographical zones and the different vines phenological behaviour or wine qualities from diverse production areas. This latter information is needed for deepening and more extended data sampling. Precise vineyards monitoring, wine analysis and wine tasting, will have to provide the information for such comparative researches.

SRI data compared to the altitude of the vineyards represents an interesting new key to the geographical peculiarities of this wine-growing territory allowing us to distinguish in detail the topoclimate differences between vineyards or wine-growing areas. Associated with the ecological information obtained from the VGI method, the data allow us to recognize and classify in great detail the winegrowing geographical units at a regional scale as well as at the scale of individual vineyards.

The geospatial analysis of metadata has made it possible to summarize complex elements in simpler and more accessible frameworks, for example by introducing geographical maps with precise indications of vineyards and wines. This will be increasingly useful for the correct interpretation of quality and for geographical location of wines. The procedure and indices adopted for evaluation and prediction of the territoriality of wine can be extended to a global perspective as effective tools for assessing abiotic stresses in plant physiology and biogenetics, including the adaptation of plants to climate change.

This study confirms how geographical terroir indicate the preferential locations of vines and wines. Specific production areas have been identified as more dedicated to certain quality wines, therefore constituting a reference for the analysis of environmental indicators for the whole wine region. In fact, through a precise classification of the geographical identity of the territory it is possible to better assess any connection between natural ecological resources, viticulture and wine typicity.

It has been found that the white wines of the Vinschgau and Eisacktal valleys are best combined with high solar radiation, acidic sandy soils based on silicate minerals. Pinot Noir from the Mazon unit is marked by fine, slightly alkaline soils and low SRI values. A similar geopedological situation benefits the Gewürztraminer from the Söll unit, which however needs greater amounts of solar radiation. Lagrein cultivated in Gries Moritzing is localized at low altitudes on porphyric alluvial cone with acidic, soft and ventilated sands. Cabernet and Merlot from the Bassa Atesina express themselves well at low altitudes, in a hot environment, on fine sub-alkaline soils and are favoured in areas with high SRI indexes. In South Tyrolean viticulture, vineyards' geographical and environmental conditions have always been of great importance. This is a practical requirement, since the farmlands of the Alpine valleys have a narrow range, limited between the impervious areas, the high mountain altitudes and the valley floors, originally unhealthy, swampy and often flooded. 


\section{Acknowledgements}

The author acknowledges Dr Flavio di Michele for the statistical survey, GIR Geo Identity Research for the GSA and geographical data, 4Land for the cartographic assistance on maps, the Consortium Alto Adige Wein and the many wine producers and winemakers for facilitating this research work and for their helpful comments and suggestions to improve the paper. The author thanks E. Costantini for his inspiration and useful advice.

\section{Conflicts of Interest}

The author declares no conflicts of interest regarding the publication of this paper.

\section{References}

[1] Vaudour, E. (2002) The Quality of Grapes and Wine in Relation to Geography: Notions of Terroir at Various Scales. Journal of Wine Research, 13, 117-141. https://doi.org/10.1080/0957126022000017981

[2] Moran, W. (2006) You Said Terroir? Approaches, Science and Explanations. The Terroir 2006 Conference, Davis, 19-23 March 2006.

[3] Van Leeuwen, C. and Seguin, G. (2006) The Concept of Terroir in Viticulture. Journal of Wine Research, 17, 1-10. https://doi.org/10.1080/09571260600633135

[4] Martin, A. (2013) Terroir-Towards a New Perspective. South Australian Geographical Journal, 112, 5-22. https://doi.org/10.21307/sagj-2013-001

[5] Patterson, T. and Buechsenstein, J. (2018) Wine and Place: A Terroir Reader. University of California Press, Berkeley, 329. https://doi.org/10.1525/9780520968226

[6] Costantini, E.A.C. and Buccelli, P. (2008) Suolo, vite ed altre colture di qualità: L'introduzione e la pratica dei concetti di “terroir" e "zonazione". Italian Journal of Agronomy, 3, 23-33.

[7] Van Leeuwen, C., Friant, P., Choné, X., Tregoat, O., Kounduras, S. and Debourdieu, D. (2004) Influence of Climate, Soil, and Cultivar on Terroir. American Journal of Enology and Viticulture, 55, 207-217.

[8] Van Leeuwen, C., Roby, J.-P., Pernet, D. and Bois, B. (2010) Methodology of Soil-Based Zoning for Viticultural Terroirs. Bulletin de P O.I. V., 83, 13-29.

[9] Vavoulidou, E., Avramides, E.J., Dimirkou, A. and Papadopoulos, P. (2006) Influence of Different Cultivation Practices on the Properties of Volcanic Soils on Santorini Island, Greece. Communications in Soil Science and Plant Analysis, 37, 2857-2866. https://doi.org/10.1080/00103620600832837

[10] Costantini, E.A.C., Lulli, L. and Mirabella, A. (1991) First Experiences to Individuate Soils Suitable for the Production of High Quality Vernaccia of San Gimignano. Atti simposio internazionale: La gestione del territorio viticolo sulla base delle zone pedoclimatiche e del catasto, S. Maria della Versa (PV), 29-30 Giugno 1987, 125-135.

[11] Costantini, E.A.C. (1998) Le analisi fisiche nella definizione della qualità dei suoli per la valutazione del territorio. I Georgofili. Quaderni 1998 III. La normalizzazione dei metodi di analisi fisica del suolo. Firenze, 33-57.

[12] Stimpfl, E. and Alii (2006) Zustandserhebung der Südtiroler Böden im Grunland. 
Laimburg Journal, 3, 2-73.

[13] Costantini, A.E.C. (2015) La componente pedological del terroir. Italus Hortus, 22, 15-30.

[14] Ferretti, C.G. (2019) Relationship between Geology, Soil Assessment, and Terroir of Gewürtztraminer Vineyards: A Case Study in Dolomites of Northern Italy. Catena, 179, 74-84. https://doi.org/10.1016/j.catena.2019.03.044

[15] Miller, B.A. and Lee Burras, C. (2015) Comparison of Surficial Geology Maps Based on Soil Survey and in Depth Geological Survey. Soil Horizons, 56, 1-12. https://doi.org/10.2136/sh14-05-0005

[16] Heung, B., Bulmer, C.E. and Schmidt, M.G. (2014) Predictive Soil Parent Material Mapping at a Regional-Scale: A Random Forest Approach. Geoderma, 214-215, 141-154. http://www.sciencedirect.com/science/article/pii/S0016706113003443 https://doi.org/10.1016/j.geoderma.2013.09.016

[17] Brevik, E.C. and Miller, B.A. (2015) The Use of Soil Surveys to Aid in Geologic Mapping with an Emphasis on the Eastern and Midwestern United States. Soil Horizons, 56, 1-9. https://doi.org/10.2136/sh15-01-0001

[18] Maltman, A. (2008) The Role of Vineyard Geology in Wine Typicity. Journal of Wine Research, 19, 1-17. https://doi.org/10.1080/09571260802163998

[19] Maltman, A. (2018) Vineyards, Rocks, and Soils: The Wine Lover's Guide to Geology. Oxford University Press Sheridan Books Inc., Oxford, 237 p.

[20] Wilson, J.E. (1999) Terroir. The Role of Geology, Climate, and Culture in the Making of French Wines. University of California Press, Berkeley, Los Angeles, London, 326.

[21] Jackson, R.S. (2014) Wine Science: Principles and Applications. Elsevier Academic Press, Amsterdam, 996 p.

[22] Ferretti, C.G. (2020) A New Geographical Classification for Vineyards Tested in the South Tyrol Wine Region, Northern Italy, on Pinot Noir and Sauvignon Blanc Wines. Ecological Indicators, 108, Article ID: 105737. https://doi.org/10.1016/j.ecolind.2019.105737

[23] Brady, N.C. and Weil, R.R. (2016) The Nature and Properties of Soils. Pearson, London.

[24] Carey, V.A., Archer, E., Barbeau, G. and Saayman, D. (2008) Viticultural Terroirs in Stellenbosch, South Africa. II. The Interaction of Cabernet-Sauvignon and Sauvignon Blanc with Environment. Journal International des Sciences de la Vigne et du Vin, 42, 185-201. https://doi.org/10.20870/oeno-one.2008.42.4.808

[25] Pedri, U. (2013) Verschiedene-Lage Andere Weine. Südtiroler Landwirt Nr. 11.07.06.2013.

[26] Pedri, U. (2014) Auswirkungen Unterschiedlicher Standorte auf Trauben und Weinqualität der Sorte Gewürztraminer. Mitteilungen Klosterneuburg, 64, 156-170.

[27] Pedri, U. and Pertoll, G. (2012) Die Auswirkung unterschiedlicher Standorte auf die Trauben und Weinqualität bei der Sorte Sauvignon Blanc. Mitteilungen Klosterneuburg, 62, 123-142.

[28] Pertoll, G., Pedri, U., et al. (2012) Lagrein: Influenza del sito di coltivazione, del terreno e delle modalità di coltivazione sulla qualità dell'uva e del vino. Frutta e vite $02 / 2012$.

[29] Pedri, U. and Pertoll, G. (2012) Der Einfluss des Standortes auf die sensorischen Eigenschaften der Weine verschiedener Rebsorten. Obst und Weinbau. 04/2013. 
[30] EURAC Research (2018) Climate Change and Consequences for South Tyrol. http://www.eurac.edu/Klimareport

[31] Konsortium Südtirol Wein (2019) Kellereien von A bis Z. http://www.Suedtirolwein.com

[32] Fischer, M., Rudmann-Mauer, K., Weyland, A. and Stöcklin, J. (2008) Agricultural Land Use and Biodiversity in the Alps. Mountain Research and Development, 28, 148-155. https://doi.org/10.1659/mrd.0964

[33] Sitzia, T. and Trentanovi, G. (2011) Maggengo Meadow Patches Enclosed by Forests in the Italian Alps: Evidence of Landscape Legacy on Plant Diversity. Biodiversity and Conservation, 20, 945. https://doi.org/10.1007/s10531-011-0006-3

[34] ISPRA (2012) Carta geologica d'Italia scala 1:50.000. https://www.isprambiente.gov.it/Media/carg

[35] ISPRA (2012) Carta Geologica d'Itlalia alla scala 1:100.000 con "Note illustrative". http://193.206.192.231/carta_geologica_italia/default.htm

[36] Gruber, F.E., Baruck, J., Mair, V. and Geitner, C. (2019) From Geological to Soil Parent Material Maps-A Random Forest-Supported Analysis of Geological Map Units and Topography to Support Soil Survey in South Tyrol. Geoderma, 354, Article ID: 113884. https://doi.org/10.1016/j.geoderma.2019.113884

[37] Provincia Autonoma di Bolzano (2020) Geological Maps on Scale 1:50.000 (CARG) and Scale 1:100.000 (Servizio Geologico Nazionale).

http://www.provincia.bz.it/informatica-digitalizzazione/digitalizzazione/open-data/ maps-e-webgis-geobrowser.asp

[38] Brandner, A. (1980) Tirolatlas: Geologische und Tektonische Übersichtskarte von Tirol. Universitätsverlag Wagner, Innsbruck.

[39] Provincia Autonoma di Bolzano (2017) Relazione Agraria \& Forestale 2017. Athesia Druck S.r.l., Druckerei, 198.

http://www.provincia.bz.it/agricoltura-foreste/agricoltura/relazione-agraria-forestal e.asp

[40] Chorti, E., Guidoni, S., Ferrandino, A. and Novello, V. (2010) Effect of Different Cluster Sunlight Exposure Levels on Ripening and Anthocyanin Accumulation in Nebbiolo Grapes. American Journal of Enology and Viticulture, 61, 23-30.

[41] Weaver, R.J. and McCune, S.B. (1960) Influence of Light on Color Development in Vitis Vinifera Grapes. American Journal of Enology and Viticulture, 11, 179-184.

[42] Ferretti, C.G. (2019) UGA Unità geografiche aggiuntive Alto Adige Südtirol. Analisi e descrizione delle zone ristrette. Consorzio vini Alto Adige. 279 p.

http://www.provincia.bz.it/agricoltura-foreste/agricoltura/downloads/6_2019_03_L agenbericht_definitiv_klein.pdf

[43] Conde, C., Silva, P., Fontes, N., Dias, A.C.P., Tavares, R. M., Sousa, J.M., Agasse, A., Delrot, S. and Gerós, H. (2007) Biochemical Changes throughout Grape Berry Development and Fruit and Wine Quality. Global Science Book.

[44] Dohrmann, R. and Kaufhold, S. (2009) Three New, Quick CEC Methods for Determining the Amounts of Exchangeable Calcium Cations in Calcareous Clays. Clays and Clay Minerals, 57, 338-352. https://doi.org/10.1346/CCMN.2009.0570306

[45] Waskom, M., et al. (2020) Seaborn 0.10.1: Statistical Data Visualization. Seaborn.pydata.org.

[46] Crippen, D.D. and Morrison, J.C. (1986) The Effects of Sun Exposure on the Compositional Development of Cabernet Sauvignon Berries. American Journal of Enol- 
ogy and Viticulture, 38, 235-242.

[47] Bergqvist, J., Dokoozlian, N. and Ebisuda, N. (2001) Sunlight Exposure and Temperature Effects on Berry Growth and Composition of Cabernet Sauvignon and Grenache in the Central San Joaquin Valley of California. American Journal of Enology and Viticulture, 52, 1-7.

[48] Smart, R.E., Smith, S.M. and Winchester, R.V. (1988) Light Quality and Quantity Effects on Fruit Ripening for Cabernet Sauvignon. American Journal of Enology and Viticulture, 39, 250-258.

[49] Silacci, M.W. and Morrisopn, J.C. (1990) Changes in Pectin Content of Cabernet Sauvignon Grapes Barries during Maturation. American Journal of Enology and Viticulture, 41, 111-115.

[50] Bora, F.D., Donici, A., Oşlobanu, A., Fitiu, A., Babes, A.C. and Bunea, C.I. (2016) Qualitative Assessment of the White Wine Varieties Grown in Dealu Bujorului Vineyard, Romania. Notulae Botanicae Horti Agrobotanici Cluj-Napoca, 4, 593-602. https://doi.org/10.15835/nbha44210434

[51] Dipoli, P. and Bampi, F. (2019) Der Sauvignon Blanc in Südtirol. Retina. Bolzano. 94.

[52] Zilioli, D.M. and Bini, C. (2009) Dieci anni di ricerche pedologiche in ambiente alpino: Considerazioni sulla distribuzione e sull'evoluzione dei suoli nella regione dolomitica. Studi Trentini di Scienze Naturali, 85, 61-68.

[53] Stimpfl, E. and Alii (2006) Zustandserhebung der Südtiroler Böden im Obstbau. Laimburg Journal, 3, 74-134.

[54] Thalheimer, M. (2006) Kartierung der landwirtschaftlich genutzten Böden des Überetsch in Südtirol (Italien). Laimburg Journal, 3, 135-177.

[55] Rauzi, G.M. (1963) Indagine chimico-comparativa fra terreni e foraggi dell'Alto Adige e suoi riflessi nel campo agronomico e zootecnico. Accademia Roveretana. Serie IV Volume III, B, 39-64.

[56] Reto, D.J., Geitner, C., Gruban, W. and Tusch, M. (2006) Soil Evaluation in Spatial Planning, a Contribution to Sustainable Spatial Development. Results of the EU-Interreg IIIB Alpine Space Project. TUSEC-IP. 47 p.

[57] Angelucci, G., Dessì, G. and Stefani, M. (2006) Interner Endbericht zu Arbeitspaket 4 "Öffentlichkeitsarbeit" für das Projekt TUSEC-IP im Rahmen der EU-Gemeinschaftsinitiative Interreg III B Alpenraum. (Koordination Arbeitspaket 4: Autonome Provinz Bozen-Südtirol, Landesagentur für Umwelt)-Bozen. 19 p. 